\title{
LEARNING NATIONAL IDENTITY OUTSIDE THE NATION-STATE: THE STORY OF LATVIAN PRIMERS (MID-1940S - MID-1970S)
}

\author{
Iveta Ķestere \\ University of Latvia, Latvia \\ Baiba Kaḷke \\ University of Latvia, Latvia
}

\begin{abstract}
In order to understand how the concept of national identity, currently included in national legislation and curricula, has been formed, our research focuses on the recent history of national identity formation in the absence of the nation-state "frame", i.e. in Latvian diaspora on both sides of the Iron Curtain - in Western exile and in Soviet Latvia. The question of our study is: how was national identity represented and taught to next generations in the national community that had lost the protection of its state? As primers reveal a pattern of national identity practice, eight primers published in Western exile and six primers used in Soviet Latvian schools between the mid-1940s and the mid-1970s were taken as research sources. In primers, national identity is represented through the following components: land and nation state iconography, traditions, common history, national language and literature. The past reverberating with cultural heritage became the cornerstone of learning national identity by the Latvian diaspora. The shared, idealised past contrasted the Soviet present and, thus, turned into an instrument of hidden resistance. The model of national identity presented moral codes too, and, teaching them, national communities did not only fulfill their supporting function, but also took on the functions of "normalization" and control. Furthermore, national identity united generations and people's lives in the present, creating memory-based relationships and memory-based communities.
\end{abstract}

Keywords: national identity, nation state, Western exile, Soviet Latvia, primers.

\section{Introduction}

In 2019, the Diaspora Law was adopted in Latvia, the law aiming to strengthen the Latvian identity of the national community abroad (Diasporas likums, 2019, Art. 4). The law provides for state support and guardianship in respect of classical components of national identity, i.e. cultural heritage, history, and language, and obliges governmental institutions to promote the acquisition of Latvian culture, Latvian history, and the official language 
of Latvia in the diaspora. Doubtlessly, acquisition means nothing else but education, and, therefore, a key role in the implementation of the "principle of affiliation to the Latvian nation" is given to formal and non-formal education, which is the responsibility of the Ministry of Education and Science (Diasporas likums, 2019, Art. 6). Strengthening of national identity within the Latvian education system is also decreed by the Regulations of the Cabinet of Ministers of 2016, which proposes promoting student "awareness of national identity and statehood, loyalty to the State of Latvia, the Constitution, and patriotism" (Izglìtojamo audzināšanas vadlīnijas..., 2016, Art. 6.9).

Thus, national identity falls under protection, supervision, and control of the state through its education system. In this way, Latvia fits into the classic category of the nation state, because, as Tröhler writes, "the nation state, depending on loyal citizens, is deeply educationalized," (Tröhler, 2020, 10) and it is a noble duty of the modern mass school system in different nation states to create distinguishable citizens of particular nations (Tröhler, 2016, 282). However, in Latvia, the relationship between the state for one part and national and ethnic identities and nationalism for another is not as obvious as it is in the case of "big" and "self-confident" Western countries. As other Baltic nations, Latvians are one of the national communities that established their state only four generations back, lost it three generations back, and regained it one generation back. For 50 years, the Latvian diaspora was separated by the Iron Curtain: some Latvians became war refugees in the West and shaped their lives outside Latvia, but Latvian identity was also endangered in the homeland, which was part of the USSR. The experience of threat to national identity is deeply ingrained in Latvian collective memory (Šūpule, 2012). Since today, in Latvia, 70-80\% of decision makers received their education during the Cold War (Visu sasaukumu deputāti, 1990-2018, i.e. after Latvia had lost its statehood, it can be argued that the roots of active conceptualization of national identity in the modern public space may be traced in the complex course of Latvian history. Despite post-modernism and the digital age, the old-fashioned "fixity of identity" (Meynert, 2013, 27) is still topical in Latvia. In the words of Hartog (2011/2017, 119-127) and Carretero (2011, 91-105), Latvians live in a memory-based society, which means that our past controls our present.

In order to understand how the concept of national identity, currently included in national legislation and curricula, has been formed, our research focuses on the recent history of national identity formation in the absence of the nation-state frame. With Tröhler's (2020, 13-14) "national literacy" concept and Silovas's idea of the "learning of nation" $(2019,11)$ in mind, we put the following research question: how was national identity represented and taught to next generations in the national community that had lost the protection of its state? 
We chose Latvian primers published in Western exile and in Soviet Latvia as sources because the primer and the first reader teach not only reading and writing but also purposefully form children's worldview, canon of values and collective memory (Grever, Van der Viles, 2017, 288; Tröhler, 2020,11 ). The primer raises members of the national community; it is one of the tools for building national identity (Cohen, 2004, 91). The primer institutionalizes and standardizes national identity, making it tangible through images and texts. It can be said that the primer reveals a pattern of national identity practice. For this study, eight primers published in Western exile and six primers used in Soviet Latvian schools between mid1940s and mid-1970s were chosen. We analyzed primer texts and images using content analysis and used the hermeneutic approach to interpret the collected material in the socio-political context of the era.

The theoretical framework of our research is based on studies of nationalism, national and ethnic identity (Carretero, 2011; Cohen, 2004; Billig, 1995; Tröhler, 2020; Šūpule, 2012). According to European Union legislation (Consolidated Version..., 2012, Art. 4(2)) and academic research, national identity is linked to the particular cultural context of a single country (Tröhler, 2016), state and nation. In turn, ethnic identity is formed in communities that do not have their own nation state, do not live in their own nation state, or are not rooted in a specific territory. In the case of Latvians, national and ethnic identities are closely intertwined, as revealed further in this study. We define national identity as a subjective sense of belonging and solidarity with a territorial community, the community which has collective memory and shares history, culture and language, all that giving a sense of security, continuity, and uniqueness (Calhoun, 2016, 12, 14; Cohen, 2004, 88, 91) - "who 'we' are and who others are not" (Tröhler, 2020, 14). We will analyze the representation of national identity through its classical components: (1) land and nation state iconography; (2) ethnic and national traditions; (3) common past, present, and future; and (4) national language and literature (after Cohen, 2004). Although Cohen also emphasizes religious affiliation as an important marker of ethnic identity, we disregarded this criterion, because for Latvians, who are predominantly Lutheran or Catholic, religion is not an important factor for inclusion or exclusion in the national community.

\section{Historical background. The Latvian community in the West and in Soviet Latvia}

Establishment and liquidation of the Latvian state. In the mid$19^{\text {th }}$ century, Latvia - then a province of the Russian Empire - experienced a rise of nationalist sentiment typical of Europe at that time, but the idea 
of Latvia as a nation state was realized after the First World War. Latvia was founded as a liberal parliamentary democracy after the collapse of the Russian empire in 1918, however nation building began only after battles against foreign forces and local Bolsheviks had been won. The establishment of the nation-state was welcomed by all segments of society, as it meant the liberation from Russian rule and the power of German landlords and as such undoubtedly raised the self-esteem of Latvians. Traditional symbols of ethnic identity such as festivals, songs, and folk costumes were complemented with national symbols - flag, hymn, coat of arms, national heroes and memorial sites. In Tröhler's terms, the creation of the state served to "organize," "normalize" and "politicize" the ethnic community (Tröhler, 2020, 8, 10-11).

The existence of the Latvian state came to an end in 1940, with its occupation and inclusion into the Soviet Union as one of the 15 Soviet Republics. Concurrently, with arrests and mass deportations, ${ }^{1}$ the communists began intensive ideological inculcation of their newly acquired citizens. Media broadcasted happy news of the Latvian nation having been included in the teaming mass of Soviet people. Newspapers proclaimed: "No longer does [Latvian] chauvinism separate us from our vast Fatherland the brotherly nations of the USSR" (D. S., 1940, 36-37). Symbols of Latvian national statehood became banned.

The Soviet occupation was followed by the Nazi occupation in 1941, and the latter's plans also did not include the restoration of the independent Latvia. In 1944, it became clear that the Soviets would return, and, fearing Stalin's repressions, about 125,000 Latvians fled to the West (Zalkans, 2014, 50). A significant group among them were Latvian intellectuals: writers, artists, academics (Plakans, 2011, 382). It is estimated that at the end of the Second World War, about 50\% of Latvian intelligentsia became refugees (Zake, 2010, 33) and later formed the nucleus of Latvian communities abroad. This is an important fact because it is intelligentsia that play a major role in national movements, they are those agents who are capable of championing the idea of national unity, who elevate it to the level of ideology and use it against the dominance of "others" (Jaffrelot, 2003, 11, 23, 33, 43-44).

Thus, in 1944/1945, Soviet dictatorship replaced the Nazi occupation and continued the Sovietization of Latvia, the process having launched in 1940/1941 and manifested in political and social repression and censorship

${ }^{1}$ On 14 June 1941, 15,424 people (among them approximately 100 newborns and more than 3000 children under 16) were deported to Siberia and Kazakhstan from Latvia. In total, in 1941, approximately 100,000 people were deported from the Baltic States (Bleiere, Butulis, 2005, 227; Levin, 1995, 15). 
of Latvian cultural heritage and history as well as Russification. All Latvian educational institutions were incorporated into the unified USSR education system.

Latvian education in Western exile. In the West, Latvian refugees were settled in Displaced Persons (DP) camps in American, British, and French zones of post-war Germany, that were united as West Germany in 1949. The refugees were financially provided, and their lives were regulated by international bodies operating under the auspices of the United Nations. With the support of these institutions and the enthusiasm of Latvian refugees themselves, in a short time in DP camps 242 educational institutions working in the Latvian language were created. In 1946/47, in the newly founded orphanages, kindergartens, primary schools, vocational schools and gymnasiums studied 15,520 Latvian children and youth (Staris, 2004, 11). Among the refugees there were about 3,000 teachers (Staris, 2004, 10), who gladly continued to work in their profession. The teachers were joined by other members of the intelligentsia, who, in the monotonous daily life of the DP camps, were happy to devote themselves to teaching children. Thus, already in the first years of exile, a unique situation arose, that is, outstanding scientists and university professors worked in Latvian schools. For example, in the DP camp Insula, with about 600 Latvian refugees living in military barracks in Bavaria, secondary school pupils learned Latin, English, German, algebra, geometry, trigonometry, art, music and theatre (Zake, 2010, 32).

In late 1940s and 1950s, several Western countries agreed to receive war refugees and the emigration of Latvians from Germany to more than 20 different countries of the world began. The most significant Latvian exile communities were formed in the USA, Canada, West Germany, England, Australia and Sweden (Staris, 2004, 18). As Latvian refugees were no longer concentrated in one place, Latvian schools ceased to operate. ${ }^{2}$ In accordance with local laws, Latvian children began to study in schools of their host country but continued to learn Latvian history, the Latvian language, Latvian geography, religious studies, singing, dancing and

${ }^{2}$ The exception was the full-time Latvian gymnasium (Minsteres latviešu gimnāzija [MLG]] - Lettisches Gymnasium Münster), opened in West Germany in 1945. In 1957, it moved from a DP camp to Münster, where it operated until 1998. MLG̣ was funded by the West German government with the participation of Latvian donors. Latvian students from all over the world came to this school; it had 53 graduating classes with 600 graduates from almost every continent. The diploma from MLG was internationally recognised (Minsteres latviešu gimnāzija, 1999). Several modern-day Latvian politicians graduated from this school. The Latvian language was recognised as a full-fledged subject in 1975 in secondary schools in several Australian states, and Western Michigan University offered an academic degree in Latvian starting in 1966. 
games on Saturdays or Sundays (Sandersa, 1977, 47). Thus, Latvian heritage language schools in the West came to be known as "Saturday" or "Sunday" schools. Such institutions operated in all Latvian communities, with the largest and most numerous schools located in the United States, Australia, Canada, England, and West Germany (Dunsdorfs, 1977, 122). Latvian education was usually financed by local Latvian communities, congregations, and occasionally by host country municipalities.

National identity issues. Although the Latvian diaspora was separated by thousands of kilometers, different political and cultural contexts, and difficulties in communicating and meeting, there were several similarities in the situation of Latvian children on both sides of the Iron Curtain: (1) the national community had lost its national statehood and, consequently, the support and protection of state institutions; (2) the identity of the national community was challenged by the proximity of larger national communities and the associated threat of assimilation; and (3) as children so their parents and teachers had to learn to integrate into an absolutely new world, in which everyday practices of national communities were restricted or banned.

In the West, Latvian identity was questioned and redefined by inevitable adaptation, the process "turning [immigrants] into objects of integration and professional intervention" (Padovan-Özdemir, Ydesen, 2016, 427). Although the host countries encouraged integration, Latvian refugees did not identify themselves with the traditional image of low-skilled, culturally different and craving for assimilation immigrants, the typical portrayal Western academic research focuses on and reproduces (e.g., Ogbu, Simons, 1998).

Similarly children who remained in Latvia no longer grew up in their traditional national community but were forcedly included into the Soviet nation, where the strict national hierarchy conferred elite positions to Russians. Russian was declared the "common language of co-operation" and the Program of the Communist Party referred to the "wiping out [of] national differences, chiefly the linguistic ones" (XXII sjezd..., 1962, 313). Latvia was flooded by Russian-speaking immigrants from all over the Soviet Union, that was clearly reflected in the dramatic decline in the number of Latvian schools. So, in 1945, Latvian was the language of instruction for $78-79 \%$ of pupils, but by 1963, the number dropped to 55\% (Beleire, Butulis, 2005, 358). This led to the tension between Latvian national consciousness for one part and the "supranational," "multi-faceted," "state-wide" Soviet identity with the associated threat of assimilation into the Soviet Russian nationhood for another, and resulted in many complex and contradictory outcomes (Silova, 2019, 5; Šūpule, 2012; Wojnowski, 2015, 3).

In the post-war situation, Latvian children and young people could be described as forced refugees: they "had been uprooted from all they 
knew and been displaced in history" (Grosvenor, Roberts, 2018, 334) even though they continued to live in their homeland. In reference to the "banal nationalism' concept (Billig, 1995, 38), many reminders or "flaggings" of Latvian national identity, routine symbols and habits were banned or restricted both in the West and in the USSR. For example, decorating public spaces with national flags, street names, postage stamps, and peoples' given names were brought into conformity with a foreign language of the "other" (Antonsich, Skey, 2016, 7, 12, 14). Deprived of banal nationalism, which may also be perceived as a top-down framing of the nation, the Latvian nationhood was narrowed to the boundaries of family and informal activities. Outside pressure from large nations forces smaller national communities to consciously or unconsciously cling togehter and actualize their identity while cherishing the hope for a better collective future (Cohen, 2004, 95, 96; Maynert, 2013, 138).

\section{Context for creation of Latvian primers. Authors}

The "re-planting" of the national diaspora into a completely new world necessitated the creation of new school textbooks, including primers. The creation of afterwar primers raised an important question at both formal and informal levels, namely, what values had to be passed on to future generations, the generations to grow up in a society completely unknown to their ancestors? In a situation when the national statehood was lost, national or ethnic identity became the central organizing concept; thus, in Western exile and under the censorship in Soviet Latvia, the formation or learning of national identity through primers became an important issue.

Initially, Western DP camp schools used, rewrote and reprinted textbooks brought from Latvia. The situation improved when Latvians created their own publishing houses in Chicago, Nuremberg, Ohio, Stockholm, Munich, and other cities. For example, in 1946 in Germany, there was reprinted a Latvian primer of 1924 written by writers and teachers Jānis Ezeriņš (1891-1924) and Jānis Grīns (1890-1966); the same book was also reprinted later, in 1953, and in 1958, in Stockholm, where Grīns himself lived in exile. Eduards Zicāns (1884-1946), a teacher, theologian and writer, wrote a new primer in the mid-1940s, which was first published in Germany and reprinted again in the USA in 1953 and 1957. Latvian primers were also published in Canada and Australia. The authors of these textbooks represented the cultural memory of Latvians as a national community, which, according to Erll, includes both the individual and the collective side as well as remembering and, most importantly, forgetting (Erll, 2011).

In the afterwar Soviet Latvia, all textbook publishing was under the state control and subject to strict Soviet censorship. The use of books published 
in the independent Republic of Latvia was forbidden; moreover, the books themselves had to be destroyed. In 1944, censors reported to Moscow that 2,500 books had been removed from twelve Riga school libraries (Strods, $2010,143,145-146,156,168,181)$. Instead, Latvian schools used versions of Russian textbooks translated in Latvian. Further, for creating new primers there were invited Latvian scholars who had proved their loyalty to Soviet authorities. Thus, the first Soviet Latvian primers and readers were authored by the philologists and teachers Kārlis Krauliņš (1904-1981) and Zenta Lubāniete (1907-1978). Although they created their textbooks under Stalin's dictatorship and strict censorship, both Krauliņš and Lubāniete nevertheless belonged to the Latvian national community. Similarly to the authors of exile textbooks, they received their education in the independent Latvia of the 1920s, so they were well acquainted with Latvian national and ethnic background.

\section{Representation of national identity in primers}

Land and state. The state was abolished, but the land of Latvia remained where it had been, and it was depicted as a wonderful place in primers published on both sides of the Iron Curtain. Primers made the "Homeland's symbolic power" (Cohen, 2004, 97) tangible. In the West, an ideal, frozenin-time image of the homeland was intensified by the fact that Latvia was "locked down" - the borders of the USSR were closed.

Both exile and Soviet primers presented plenty of iconic images of Latvia: the capital of Riga with its panorama, lush gardens and wide streets, typical Latvian trees - oaks, ashes and lindens, the largest rivers Daugava and Gauja, idyllic Latvian rural landscapes (Krauliņ̌s, 1946, 30; Roga, Cīrulis, 1947; Zicāns, 1948, 97; Lubāniete, Bērzāja, 1955, 110).

There were, of course, differences among exile and Soviet primers, the dissimilarity dictated by the political context. In Soviet primers, Latvia was always called the Latvian SSR, the abbreviation for a Soviet Socialist Republic, thus emphasizing Latvia's membership in the Soviet Union. In addition to Riga, Moscow as the capital of the "big homeland" or the USSR occupied an important place in the Soviet primers; there was no shortage of symbols of Soviet life in Riga such as the Pioneer Palace, red flags, Lenin Street. In turn, in the exile primers, the image of Latvia was frozen in the past and Latvia's status as a part of the Soviet Union was never mentioned.

The symbols of Latvian statehood were completely excluded from Soviet primers; they were replaced with Soviet symbolism, myths, and rituals. The Latvian flag, coat of arms, anthem, and portraits of state leaders were banned, as were press publications, books, films, songs, and other elements 
of Latvian cultural heritage; all of them were deemed threatening to Soviet rule. The prohibition of national symbols and cultural values was taken hard by the majority of Latvians as it clearly demonstrated the loss of statehood. Overt opposition to the Soviet regime, most often demonstrated by pupils, took form of hanging the Latvian flag on towers and distributing anti-Soviet leaflets (Kreegipuu, Lauk, 2007; Plakans, 2011, 362-363). Any display of symbols of the Latvian state resulted in severe punishments: during the Stalin era, many teachers and students were arrested by the $\mathrm{KGB}^{3}$ and sent to concentration camps deep in Russia for dozens of years; in later years, many students were expelled from educational institutions (Rimšāns, 2007; Vilciņš, 1997).

Whereas symbols of the nation state became a means of resistance to the Soviet dictatorship, in the West their inclusion in Latvian primers was only expected. The state of Latvia was referred to in the present: "Latvian soldiers defend their country and the honour of the Latvian flag" (Zicāns, 1948, 97). For 50 years, Latvian children in exile studied the iconography of a non-existent nation state, with its symbols becoming an indispensable part of Latvian ethnic identity.

National/ethnic traditions. Visually, belonging to Latvian national community was demonstrated through the national costume. In the $20^{\text {th }}$ century, the use of Latvian folk costumes was widespread: they were worn at festivals and sometimes at school graduations, choirs and dance groups sang in folk costumes, and people attended concerts and celebrated family events, even weddings, wearing them. Therefore, in both exile and Soviet primers, people dressed in folk costumes were not an uncommon occurrence; moreover, they were distinctly positive characters who carried a clear moral message, that is, being Latvian meant impeccable behavior.

In the exile primers, virtually all people were dressed in folk costumes. Iconic images of young people in national dress are found on the covers of primers and next to the letters to be learned. In the Soviet primers, folk costumes were worn by family members, but mainly at public events people in folk costumes attended Soviet holiday mass gatherings such as, for example, the May Day parade. Inclusion of the national costume in Soviet traditions sent the message that Latvians had been included in the new Soviet way of life.

However, the "life" of the Latvian national costume in the public space through school was an important manifestation of national identity, unattended and underestimated as such by Soviet censors. In the eyes

${ }^{3}$ KGB (Komitet Gosudarstvennoy Bezopasnosti in Russian) - The Committee for State Security of the Soviet Union. 
of the Soviet elite, the Latvian national costume was only a beautiful indigenous ornament; its task was "to serve cosmetically to beautify aspects of power" (Scott, 1990, 52). Latvians, on the other hand, had grown up with the history of this attire, the lore passed down from generation to generation: Latvian folk dress was a proof of belonging to the lowest social strata - Latvians - who had been mostly peasants. Latvian folk costumes had never been worn by "masters", and the latter had never been in short supply in Latvia. Thus, Latvian national dress became a code of affiliation, a symbol of solidarity of the "inner circle" that "strangers" saw but did not understand.

Another signifier of cultural heritage was festival rituals and associated symbols. Like other Europeans, Latvians celebrated Christmas and Easter, but equally important was the Midsummer Festival on 23-24 June, the celebration of the longest day and shortest night. In the independent Latvia, Midsummer had the status of a national holiday.

The exile primers had illustrations of idyllic Midsummer celebrations on a Latvian farmstead, where people, adorned with wreaths and flowers, gathered in folk costumes by a massive oak tree (Zicāns, 1948, 95). Midsummer was more problematic in Soviet Latvia, where Soviet censors periodically allowed or forbade its celebration. Therefore, in the Soviet primers Midsummer was never named. However, the 1949 primer depicts girls in folk costumes in a meadow of flowers, with oak wreaths in their hands (Lubāniete, 1949, 54). This image appears to be politically innocent, but its connection with the canon of Latvian culture is clear - in Latvian folklore the oak is a symbol of strength, and only once a year, on Midsummer, are wreaths woven from its branches. This image opens the door to interpretation, i.e. in the classroom the teacher could discuss it as a beautiful pastoral landscape or dare to use it to teach national traditions.

Representation of the past, present and future. The time in which the national community "lives" in the primers is telling, and that is where the most significant differences among exile and Soviet books can be found.

Characters in the exile primers are dressed in peasant costumes of old times. They live in the patriarchal environment of a typical Latvian homestead, labor on performing their daily chores, namely, herding animals, grinding grain, and nurse babies in old-fashioned cradles. The present and life in their adopted countries do not exist; the only goal is to return to Latvia: "Latvians love their farms. This is their Homeland, which they do not willingly separate with. Those who have gone abroad want to return to their homeland" (Zicāns, 1948, 97). Only in the few primers published in the 1960s does the tone change, and that happens for the next generation of Latvians born in exile, with refugees having adapted to their new homeland and with the hope of returning to Latvia having disappeared. 
Soviet authorities put a great deal of effort into rewriting histories of occupied nations, including those of the Baltic states. Ideologically "correct" official versions of the past allowed neither deviation nor varying interpretations; all possible alternative information sources were blocked (Kreegipuu, Lauk, 2007, 43, 48). The first post-war Soviet primers were distinctly focused on innovations that were introduced in Latvia after its inclusion in the USSR. All Soviet primers contained illustrations, stories, and poems about collective farms and Soviet holidays, little Octobrists and young Pioneers, the Soviet Army and military equipment, Lenin and Stalin, and the friendship between the peoples of the USSR. These phenomena were intensely and aggressively inculcated in Latvian milieu by using both Latvian personal names and folklore. For example, Shura and Sasha (typical Russian first names) in Russian folk costumes are visiting Aina (typical Latvian first name) dressed in a Latvian folk costume (Lubāniete, 1949, 81), or Balvis, who is Latvian, is portrayed as a Young Pioneer (Lubāniete, Bērzāja, 1955, 76). All Soviet innovations were presented in a very positive light: for example, "nice, new tanks" (Lubāniete, 1949, 54). Latvians are pointedly depicted as part of the great Soviet nation, with their common path leading to a happy future. Latvia's recent past is completely excluded from the primer, the sensitive issues of the former existence of the independent Latvian state and its cultural heritage are avoided.

National language and literature. Even when the mother tongue is not used in everyday life, it always remains an important symbol of national culture and forms a "common milieu" (Calhoun, 2016, 13; Cohen, 2004, 99). Although Latvians in exile had no rational or "instrumental reasons" in Laitin's words (Laitin, 2007, 59) to learn their mother tongue, some members of the second generation born in exile were able to communicate in Latvian, a rarity among migrants. In addition to family, the network of Latvian schools played an important role in native language proficiency. Even in Soviet Latvia, where the public space was increasingly being taken over by the Russian language, education, from pre-school to university, could still be obtained in Latvian.

In all primers, learning of the mother tongue began with extremely rich Latvian folklore: in addition to about three million folk songs, there is a wide range of fairy tales, legends, riddles, and anecdotes. Latvian folklore encodes the entire daily life of the nation, its most important values and adages. The moral model created by folklore is timeless and "all-rule-safe", so Latvian folklore, and especially folk songs, has presented rewarding material for primers in all times.

All exile primers contain a wide range of folk songs, legends, fairy tales, proverbs, and riddles. For example, in the primers published in 1947 and 1963, next to each letter there was a corresponding folk song (Roga, Cīrulis, 
1947; Rietuma, 1963). The Soviet primers printed in 1946 and 1949 also contain folk songs, folk riddles, and fairy tales. Folklore can not be found in the primers of the 1960s, because the communist struggle against "Latvian nationalists" had begun (see Prigge, 2015), but in the 1970s, folklore returned. Thus, in 1976, almost every page once again contains a Latvian folk song or a riddle (Nesterovs, Osmanis, 1976).

In the Soviet primers, Latvian folklore as well as national costumes underwent rather curious adaptation to Soviet propaganda. In the 1955 edition, in addition to Latvian folk songs, there are "Soviet folk songs" that mimic the rhythm and style of Latvian ones but talk about the specifics of Soviet life. For example, "Strangers wonder, is this Riga or Jelgava? Neither Riga, nor Jelgava, but a kolkhoz ${ }^{4}$ is built" (Lubāniete, Bērzāja, 1955 , 79). Sometimes folk songs were linked to symbols of the Soviet state; for example, next to a folk song about the "beautiful fatherland", a picture of the map and flag of Soviet Latvia could be found (Nesterovs, Osmanis, 1976, 91).

Fictional literature also became a tool for acquiring national identity: plot lines modelled "the situation of multiple biographies in national narratives. ... They cultivated a way of imaging that in turn supported the integration of self and nation. ... It was the way of constituting the nation through shared imagination" (Calhoun, 2016, 13-14). Next to folklore, Latvian primers placed short fragments of fiction, but the question of authors was obviously a sensitive one. In the exile primers, they primarily looked into the past and chose Latvian literary classics. Later those were gradually supplemented by works from the vast range of exilic literature and by only one female writer living in Soviet Latvia. Literature of other nations was not cited at all.

On the other side of the Curtain, in Soviet Latvia, the recent past was forbidden to mention, thus, in the 1946 primer the authors of texts and poems were not identified, that can be explained by the uncertainty about which authors might be allowed and which might be banned by Soviet censors. Some Latvian authors known to be Soviet propagandists are identified in the 1949 primer, but in the 1950s, excerpts by Latvian Soviet writers are supplemented with translations of Russian texts. Exile literature created in the West was, of course, not used, as its very existence was concealed throughout the Soviet era and its illegal reading threatened with repressions from the KGB.

${ }^{4}$ Kolkhoz (kollektivnoye khozaystvo in Russian) - collective farm in the Soviet Union. After the Second World War, kolkhozes were compulsory introduced in Latvia. 


\section{Conclusions}

The loss of the national statehood, the massive presence of "others," the threat of leveling with the majority or assimilation, and, importantly, restrictions on the freedom of choice stimulated the cohesion of Latvian community on both sides of the Iron Curtain. Such familiar and understandable components of national identity as land iconography, traditions, common history, national language and literature became the cornerstone of self-organization. The symbols of the nation state were included in community traditions, taking an equal place next to other representations of Latvian identity. Without the actual state, its symbols became part of collective culture and were used in the same way as other components of ethnic identity, the components redefined and re-activated in the new post-war world.

In Western exile, national identity gave a sense of security in a foreign environment and served as an expression of attitude towards the aggression of the Soviet Union against the Baltic states. In turn, the preservation and cultivation of national identity in Soviet Latvia became a means of hidden resistance to Soviet dictatorship and Russification. Education, through which national identity was shaped, stereotyped, and taught to future generations, played an important role in the diaspora's self-preservation. As Franzenburg, Iliško, and Verkest describe the Latvian experience, "By focusing on their [Latvian] mother tongue and motherland, illustrated by songs, symbols, sermons and narratives, they gained the power to cope with experiences of minority-existence ..." (Franzenburg, Iliško, Verkest, 2018, 118).

The past reverberating with cultural heritage became a solid foundation for learning national identity. The Latvian primers homogenized cultural heritage, and its core was the same both in exile and in Soviet Latvia. The symbolic power of the homeland was converted into the power of the past. The common idealized past was contrasted with the present and the future into the Soviet Union. However, the history of Latvians in the primers is not represented as a story of victims, which is typical in cases of "resistant identity" (Carretero, Perez-Manjarrez, 2014, 73), it is more of nostalgia for an ideal land and a society that "lives" forever. The past linked the present and the future (Kattago, 2009, 3); the past being allinclusive, it united generations and people's lives in the present, creating memory-based relationships and memory-based communities. The common past became a "safe haven" where the "need of belonging" was a response to threats from "others" and compensation for humiliation (Tamm, 2016, 136; Kestere, Ozola, 2019). "Roots fixed in the past" and grand narratives of national history serve ideological purposes, that is, by providing people 
with a common past, a common identity is developed and patriotism is strengthened (Jaffrelot, 2003, 10; Kreegipuu, Lauk, 2007, 42; Van Alphen, Carretero, 2015).

The representation of national identity in primers imparted not only ideological but also moral teaching ("education as a social practice is a highly moral issue" (Tröhler, 2020, 6)), i.e. belonging to Latvian national community meant complying with high moral standards and being accountable to the community. Through the primers, respect for one's land, language and history, its beautiful visual image, and diligence were taught. The primers represented the ideal model of behavior. The image of a beautifully dressed, clean and tidy Latvian maid was a means of distancing from the images of both Western and Soviet migrants, clearly demonstrating what we, Latvians, should be. Thus, the national community did not only support but also "normalize" and control, in this way taking over the functions of the nation state.

The story of primers also helps to reveal the context of the representation and learning of national identity. In Western exile, the activities of the Latvian community were not restricted but supported by their host country; in the conditions of the Cold War, the Baltic "card" could always be played by criticizing the policies of the Soviet Union. In Soviet Latvia, national identity representation, if it did not include the symbols of Latvian statehood, was also allowed and even supported as it formed a magnificent facade for the Soviet dictatorship. Such understandable and familiar ethnic components as folk costumes and folk songs were transferred to Soviet political reality with the hope to make it more palatable and acceptable (See Calhoun, 2016, 27). However, cultural heritage, unattended and underestimated by official authorities, left the niche for hidden resistance and enabled Latvians to maintain and preserve their national identity.

It is almost paradoxical to conclude that Latvian national identity was successfully cultivated under the auspices of "great" nations and states, as it was more or less openly in opposition "to the officially sanctioned version of the nation" (Silova, 2019, 11). In the late 1980s, the components of Latvian national identity were redefined again and united exiled and Soviet Latvians, becoming symbols of the movement for liberation from the Soviet Union. Since 1991, with the restoration of the Latvian state, the Latvian education system again has been cultivating national identity and its long experience story, and 'banal nationalism' again has taken its place. However, the collective memory still retains a sense of danger (Šūpule, 2012, 14), and the old-fashioned national identity is brought up to date again and again, finding itself in the sphere of concern, support, and protection of the nation state. 


\section{References}

Ābece un lasāmgrāmata 1. klasei [Primer and Reader for Grade 1]. (1966). Nujorkas latviešu ev. lut. draudzes skolu skolotāju kopa, Amerikas latviešu apvienības kultūras birojs.

Antonsich, M., \& Skey, M. (2017). Introduction: The Persistence of Banal Nationalism. In M. Skey \& M. Antonsich (Eds.), Everyday Nationhood. Theorising Culture, Identity and Belonging after Banal Nationalism (pp. 1-13). Palgrave Macmillan.

Billig, M. (1995). Banal Nationalism. London: Sage.

Bleiere, D., Butulis, I., Feldmanis, I., Stranda, A. \& Zunda, A. (2005). Latvijas vēsture. 20. gadsimts [History of Latvia. $20^{\text {th }}$ Century]. Riga: Jumava.

Calhoun, C. (2016). The Importance of Imaged Communities - and Benedict Anderson, Annual Review, 1, 11-16.

Calhoun, G. (2014). Saints Into Soviets: Russian Orthodox Symbolism and Soviet Political Posters. Theses, Georgia State University. Downloaded from https://scholarworks.gsu. edu/cgi/viewcontent.cgi? article $=1089 \&$ context $=$ history_theses .

Carretero, M. (2011). Constructing Patriotism. Teaching History and Memories in Global Worlds. Charlotte, North Carolina: IAP.

Carretero, M., \& Perez-Manjarrez, E. (2014). Historical Narratives and the Tension among National Identities, Colonialism and Citizenship. In M. Köster, H. Thünemann \& M.Zülsdorf-Kersting (Eds.), Researching History Education. International Perspectives and Disciplinary Traditions (pp. 71-88). Frankfurt/M: Wochenschau Verlag.

Cohen, E. H. (2004). Components and Symbols of Ethnic Identity: A Case Study in Informal Education and Identity Formation in Diaspora. Applied Psychology: An International Review, 53(1), 87-112.

Consolidated Version of the Treaty on European Union (2012). Official Journal of the European Union. Downloaded from https://eur-lex.europa.eu/legal-content/EN/ $\mathrm{TXT} /$ ?uri $=$ CELEX\%3A12012M\%2FTXT.

D. S. (1940). Audzināšana skolā [Up-bringing in Schools]. Padomju Latvijas Skola [Soviet Latvian School], 1, 36-37.

Diasporas likums [Diaspora Law] (2019). Likumi LV [Legal Acts of the Republic of Latvia]. Downloaded from https://likumi.lv/ta/id/302998-diasporas-likums.

Dunsdorfs, E. (1977). Kā aplēst latviešu bērnu skaitu? [How to Calculate the Number of Latvian Children?] In E. Dunsdorfs (Ed.), Archivs. Izglitiba [Archives. Education], 17, (pp. 117-126). Melburna: Pasaules brīvo latviešu apvienība un Kārḷa Zariņa fonds.

Erll, A. (2011). Traumatic Pasts, Literary Afterlives, and Transcultural Memory: New Directions of Literary and Media Memory Studies. Journal of Aesthetics \& Culture, 3, 1-5. Downloaded from https://doi.org/10.3402/jac.v3i0.7186.

Franzenburg, G., Iliško, Dz., \& Verkest, H. (2018). Embracing the Culture of Resilience and Remembrance in Teaching Contested Historiacl Narratives. Discourse and Communication for Sustainable Education, 9(2), 111-122.

Grever, M., \& Van der Viles, T. (2017). Why National Narratives are Perpetuated: A Literature Review on New Insights from History Textbook Research. London Review of Education, 15(2), 286-301. 
Grosvenor, I., \& Roberts, S. (2018). Children, Propaganda and War, 1918-1918: An Exploration of Visual Archives in English City. Historia y Memoria de la Educación, 8, 307-345.

Hartog, F. (2011/2017). Regimes of Historicity. Presentism and Experiences of Time. Columbia University Press.

Izglìtojamo audzināšanas vadlīnijas un informācijas, mācību lìdzekḷ,u, materiālu un mācību un audzināšanas metožu izvērtēšanas kārtiba [Guidelines for the Upbringing of Learners and Procedures for the Evaluation of Information, Teaching Aids, Materials, and Teaching and Upbringing Methods] (2016). Likumi LV [Legal Acts of the Republic of Latvia]. Downloaded from https://likumi.lv/ta/id/283735-izglitojamo-audzinasanasvadlinijas-un-informacijas-macibu-lidzeklu-materialu-un-macibu-un-audzinasanasmetozu-izvertesanas-kartiba.

Jaffrelot, C. (2003). For a Theory of Nationalism. Questions de Recherche/Research Questions, 10, 1-51. Downloaded from http://dx.doi.org/10.2139/ssrn.2290897.

Kattago, S. (2009). Agreeing to Disagree on the Legacies of Recent History. Memory, Pluralism and Europe after 1989. European Journal of Social Theory, 12(3), 1-21. DOI:10.1177/1368431009337352.

Kestere, I., \& Ozola, I. (2019). German Fascism, Soviet Communism, and Latvian Nationalism in the Education of Latvia (1940-1944). Paedagogica Historica, 56(1-2), 1-18. Downloaded from https://doi.org/10.1080/00309230.2019.1669678.

Krauliņ̌s, K. (1946). Ābece. 4.izdevums [Primer. 4 ${ }^{\text {th }}$ Edition]. Rīga: Latvijas Valsts izdevniecība.

Kreegipuu, T., \& Lauk, L. (2007). The 1940 Soviet Coup-d'État in the Estonian Communist Press: Constructing History of Reshape Collective Memory. Westminster Papers in Communication and Culture, 4(4), 42-64.

Laitin, D. D. (2007). Nations, States, and Violence. Oxford: Oxford University Press.

Levin, D. (1995). The Lesser of Two Evils. Eastern European Jewry Under Soviet Rule, 1939-1941. Philadelphia, Jerusalem: The Jewish Publication Society.

Lubāniete, Z., Bērzāja, L., \& Vuškalne, L. (1955). Ābece 1.klasei [Primer for Grade 1]. Rīga: Latvijas Valsts izdevniecība.

Lubāniete, Z. (1949). Ābece mājmācỉbai un bērnu dārziem [Primer for Home-schooling and Kindergartens]. Rīga: Latvijas Valsts izdevniecība.

Lubāniete, Z., Bērzāja, L., \& Vuškalne L. (1955). Ābece 1. klasei [Primer for Grade 1]. Rīga: Latvijas Valsts izdevniecība.

Lubāniete, Z., Bērzāja, L., \& Vuškalne, L. (1952). Ābece 1. Klasei [Primer for Grade 1]. Rīga: Latvijas Valsts izdevniecība.

Lubāniete, Z., Petkēviča, Z., Ramša, A., Upmane, Z., \& Zupāne, J. (1965). Sāksim mācities! [Let's Start Learning!]. Rīga: Liesma.

Meynert, M. (2013). Conceptualizations of Childhood, Pedagogy and Educational Research in the Postmodern. A Critical Interpretation. Lund: Department of Sociology, Lund University.

Minsteres latviešu ǵimnāzija (1945-1998). Atskats uz sevišķu skolu [Münster Latvian Gymnasium (1945-1998). A Retrospective on a Special School]. (1999). Latviešu Tautas kopība Vācijā. 
Nesterovs, O., \& Osmanis, J. (1976). Ābece 1. klasei. 2. izdevums [Primer for Grade 1. $2^{\text {nd }}$ Edition]. Rīga: Zvaigzne.

Ogbu, J. U., \& Simons, D. H. (1998). Voluntary and Involuntary Minorities: A CulturalEcological Theory of School Performance with Some Implications for Education. Anthropology \& Education Quarterly, 29(2), 1998, 155-188.

Padovan-Özdemir, M., \& Ydesen, C. (2016). Professional Encounters with the Post-WWII Immigrant: a Privileged Prism for Studying the Shaping of European Welfare NationStates, Paedagogica Historica, 62(5), 423-437.

Plakans, A. (2011). A Concise History of the Baltic States. Cambridge University Press.

Prigge, D. W. (2015). Bearslayers: The Rise and Fall of the Latvian National Communists. Peter Lang.

Rietuma, O. (1963). Mēs krāsojam un mācāmies [We are Colouring and Learning]. Čikāga: Alfrēda Kalnāja spiestuve.

Rimšāns, J. (2007). Manifestations of Youth Resistance against the Communist Regime in the Latvia SSR (1965-1985). In A. Caune, D. Bleiere \& V. Nollendorfs (Eds.) Latvia and Eastern Europe in the 1960s-1980s. Materials of an International Conference 10 October 2006, Riga (pp. 116-132). Rīga: Latvijas vēstures institūta apgāds.

Roga, D., \& Cīrulis, S. (Eds.) (1947). Ābece [Primer]. Minhene: Bavārijas apgabala latviešu komiteja.

Sandersa, Z. (1977). Nepieciešamas skolu reformas [Necessary School Reforms]. In: Dunsdorfs E. (Ed.) Archivs. Izglitïba [Archives. Education], 17 (pp. 45-56). Melburna: Pasaules brīvo latviešu apvienība un Kārḷa Zariņa fonds.

Scott, J. C. (1990). Domination and the Arts of Resistance. New Haven and London: Yale University Press.

Silova, I. (2019). Lessons in Everyday Nationhood: Childhood Memories of 'Breaching' the Nation. Children's Geographies, 1-13. Downloaded from https://doi.org/10.1080/14 733285.2019.16184440.

Staris, A. (2004). Latviešu skolas un izglītība Rietumu trimdā [Latvian Schools and Education in Western Exile]. In A. Staris (Ed.) Rietumu trimdas latviešu pedagogiiskā doma [The Pedagogical Thought of Latvians in Western Exile] (pp. 9-33). Rīga: RaKa.

Strods, H. (2010). PSRS politiskā cenzūra Latvijā 1940-1990 [USSR Political Censorship in Latvia 1940-1990]. Rīga: Jumava.

Šūpule, I. (2012). Etniskās un nacionālās identitātes sociālā konstruēšana mijiedarbībā: Latvijas gadijuma izpēte. Promocijas darbs [Social Construction of Ethnic and National Identity in Interaction: A Case Study of Latvia. PhD Theses]. Latvijas Universitāte.

Tamm, M. (2016). Displaced History? A New "Regime of Historicity" among the Baltic Historians in Exile (1940s-1960s). Storia della Storiografia/Histoire de l'Historiographie/ History of Historiography/Geschichte der Geschichtsschreibung. Rivista internazionale. Revue internationale International Review Internationale Zeitschrift, 69(1), 129-146.

Tröhler, D. (2016), Curriculum History or the Educational Construction of Europe in the Long Nineteenth Century. European Educational Research Journal, 15(3) 279-297.

Tröhler, D. (2020). National Literacies, or Modern Education and the Art of Fabricating National Minds. Journal of Curriculum Studies. DOI: 10.1080/00220272.2020.1786727, $1-16$. 
Van Alphen, F., \& Carretero, M. (2015). The Construction of the Relation between National Past and Present in the Appropriation of Historical Master Narratives. Integrative Psychological and Behavioral Science, 49(3), 512-530.

Vilciņš, T. (1997). Skolu jaunatne nacionālajā cinnā (1940-1941) [School Youth in the National Struggle]. Rìga, Latvijas Valsts arhīvs.

Visu sasaukumu deputāti [All Members of Parliament] (1990-2018). Saeima.LV [The Parliament of the Republic of Latvia]. Downloaded from https://titania.saeima.lv/ Personal/Deputati/Saeima13_DepWeb_Public.nsf/farchivelist?readform\&type $=7 \&$ lang $=\mathrm{LV} \&$ count $=1000$.

Wojnowski, Z. (2015). The Soviet People: National and Supranational Identities in the USSR after 1945. Nationalities Papers: The Journal of Nationalism and Ethnicity, 43(1), 1-7, DOI: 10.1080/00905992.2014.953467.

XXII sjezd Kommunisticeskoj partiji Sovetskovo Sojuza. 17-31 oktjabrja 1961 goda. Stenograficeskij otcjot [22 ${ }^{\text {nd }}$ Congress of the Communist Party of the Soviet Union. 17-31 October, 1961, Shorthand report]. (1962). Moskva, Gosudarstvennoje izdatelstvo politiceskoj literaturi.

Zake, I. (2010). Politics of a Refugee Community. American Latvians. New Brunswick (USA) and London (UK): Transaction Publishers.

Zalkans, L. (2014). Back to the Motherland. Repatriation and Latvian Émigrés 1955-1958. $\mathrm{PhD}$ Theses. University of Stockholm.

Zicāns, E. (1948). Viegla gaita. Ābece un lasāmā grāmata [Easy Going. Primer and Reader]. Nirnberga: Tēvzemes apgāds. 